SISTEMA
ELETRONICO
DE REVISTAS
SER I UfPR

\title{
Produções, ocupações e coexistências possíveis à conservação ambiental: uma análise na Reserva Extrativista Terra Grande-Pracuúba
}

\section{Productions, occupations and coexistences possible for environmental conservation: an analysis in the Terra Grande-Pracuúba Extractive Reserve}

\author{
Alex de Castro FIUZA ${ }^{1 *}$, Samira Lima da COSTA ${ }^{2}$, Carlos Frederico Bernardo LOUREIRO² \\ ${ }^{1}$ Instituto Chico Mendes de Conservação da Biodiversidade (ICMBio), Rio de Janeiro, RJ, Brasil. \\ ${ }^{2}$ Universidade Federal do Rio de janeiro (UFRJ), Rio de Janeiro, RJ, Brasil. \\ *E-mail de contato: lexfiuza@gmail.com
}

Artigo recebido em 22 de setembro de 2017, versão final aceita em 22 de junho de 2018.

RESUMO: O sistema capitalista, atual modelo de organização social hegemônico, além de estar vinculado a um "desenvolvimento" baseado na constituição de desigualdades sociais, lançou a sociedade numa forte crise ambiental. A partir da ecologia política, assumimos a premissa que tal crise não é ambiental, mas sim social com desdobramentos na natureza, com o modelo de produção capitalista em seu cerne. Dessa forma, apresentamos neste artigo resultados de uma pesquisa que objetivou descrever e analisar a organização socioeconômica de comunidades tradicionais inseridas na Reserva Extrativista Terra Grande-Pracuúba, bem como suas relações ambientais. Nessa trajetória, partindo-se de uma abordagem psicossocial e qualitativa, foram adotadas as técnicas 'observação participante' e 'entrevistas centradas'(focused interview). Para a análise dos dados utilizou-se a técnica 'análise de conteúdo', tendo como ferramenta de suporte o Atlas TI. Foi possível constatar que os grupos sociais analisados exercem suas práticas econômicas - seu trabalho de maneira espacialmente integrada às demais práticas materiais e imateriais necessárias à sua reprodução social. Tal integração favorece a manutenção ecossistêmica de seus territórios, especialmente diante da alta mobilidade do capital. Frente às possibilidades de avanço deste modelo ambientalmente predatório sobre territórios conservados, fomentar práticas produtivas tradicionais, para além de favorecer a autonomia socioeconômica e política desses povos, tende a potencializar a conservação dos ecossistemas.

Palavras-chave: conflito ambiental; psicossociologia; povos e comunidades tradicionais.

ABSTRACT: The capitalist system, which represents the current hegemonic model of social organization, besides being 
associated with a "development" based on social inequalities, caused society to face a severe environmental crisis. From the perspective of political ecology, we assume the premise that the crisis is not environmental, but a social crisis with consequences in nature, with the capitalist mode of production at its core. Thus, we present in this article results of a research that aimed to describe and analyze the socioeconomic organization of traditional communities residing in the Terra Grande-Pracuúba Extractive Reserve and their relations with the environment. In this trajectory, considering a psychosocial and qualitative approach, the techniques 'participant observation' and 'focused interview' were adopted. For the data analysis, the 'content analysis' technique was used and Atlas Ti was used as a support tool. It was possible to verify that the analyzed social groups conduct their economic practices in a space integrated to the other material and immaterial practices necessary for their social reproduction. This integration favors the ecosystem maintenance of their territories, especially in the face of high capital mobility. When considering the possibilities of expansion of this environmentally predatory model over their conserved territories, fostering traditional production practices, not only favors the socioeconomic and political autonomy of these peoples, but also tends to strengthen the conservation of ecosystems.

Keywords: environmental conflict; psychosociology; peoples and traditional communities.

\section{Introdução}

Partindo de autores vinculados à Ecologia Política (Foladori, 2001; Loureiro \& Layrargues, 2013), é possível afirmarmos que a atual hegemonia do modo de produção capitalista, além de promover um "desenvolvimento" baseado na constituição de desigualdades (Leher, 2010), lançou a sociedade em uma forte crise ambiental. Aqueles autores partem da premissa de que os atuais problemas ambientais não estão localizados apenas na natureza, fora da sociedade: encontram-se nas relações sociais com desdobramentos na natureza, tornando-se ambientais. Nessa perspectiva, formas sociais específicas determinam problemas específicos de cada época; consequentemente, no caso das sociedades contemporâneas, o modelo de produção capitalista está no cerne do que identificamos como crise ambiental.

Muitos autores sul-americanos (Acselrad, 2004; Leroy \& Meireles, 2013; Pacheco \& Faustino, 2013) abordam essa crise através dos conflitos ambientais da região. Nos aproximamos dessa perspectiva, inclusive por compreendermos que pesquisar tais conflitos é uma estratégia de luta em direção a projetos societários mais justos, culturalmente diversos e viáveis do ponto de vista ambiental.

Assim, enquanto potências que podem contribuir com esta luta e que dão materialidade à abordagem teórica e epistêmica aqui assumida, se encontram povos e comunidades tradicionais (Brasil, 2007) detentores de conhecimentos, concepções de mundo e modos de produção distintos do modelo de desenvolvimento hegemônico.

Reconhecendo tal perspectiva transformadora e considerando a complexidade de uma realidade onde estão em estreita relação dimensões espaciais e temporais objetivas (materiais) e subjetivas (psicológicas), redigimos o presente artigo. Nele, apresentamos resultados de uma pesquisa, realizada entre os anos 2015 e 2017, que objetivou descrever e analisar a organização socioeconômica de comunidades tradicionais (Brasil, 2007) inseridas na Reserva Extrativista (RESEX) Terra Grande-Pracuúba e suas relações ambientais a partir de uma abordagem psicossocial. 
Nesta abordagem assumimos o "trabalho", ora compreendido como "o metabolismo entre o ser humano e a natureza, entre o indivíduo e os outros, objetivando o humanamente subjetivo e subjetivando o humanamente produzido" (Loureiro \& Layrargues, 2013, p.57 e 58); como categoria analítica importante para a investigação das relações entre as subjetividades individuais (universos simbólicos) e a objetividade socioambiental (universo material). Assim, concebemos o "trabalho" como categoria mediadora entre os fundamentos teóricos dessa pesquisa qualitativa: a Ecologia Política e a Psicossociologia.

As técnicas da 'observação participante' e das 'entrevistas centradas'(focused interview) foram adotadas na construção dos dados. Estes foram analisados através da 'análise de conteúdo', sendo utilizado o programa computacional Atlas Ti no suporte à organização e sistematização dos dados.

\section{O território e as comunidades}

Nos municípios de Curralinho e São Sebastião da Boa Vista (Ilha do Marajó/PA) encontra-se a RESEX Terra Grande-Pracuúba. Com uma área de 194.695,1808 hectares, ela abrange mais de vinte comunidades tradicionais distribuídas ao longo de seis rios.

Conforme art.18 da Lei 9985/2000 (Brasil, 2000) ${ }^{1}$, RESEX é uma

área utilizada por populações extrativistas tradicionais, cuja subsistência baseia-se no extrativismo e, complementarmente, na agricultura de subsistência e na criação de animais de pequeno porte, e tem como objetivos básicos proteger os meios de vida e a cultura dessas populações, e assegurar o uso sustentável dos recursos naturais da unidade.

Quando foi reinvidicada a criação da RESEX Terra Grande-Pracuúba, no ano de 1997 (Brasil/ ICMBio, 1997), o Alto Rio Canaticú era palco de um conflito ambiental no qual estavam diretamente implicadas as duas comunidades tradicionais - Timbotuba e Serafina, ambas envolvidas neste estudo - e uma empresa de extração e beneficiamento de palmito das palmeiras de açaí (Euterpe oleracea). As estruturas desativadas dessa empresa permanecem na região.

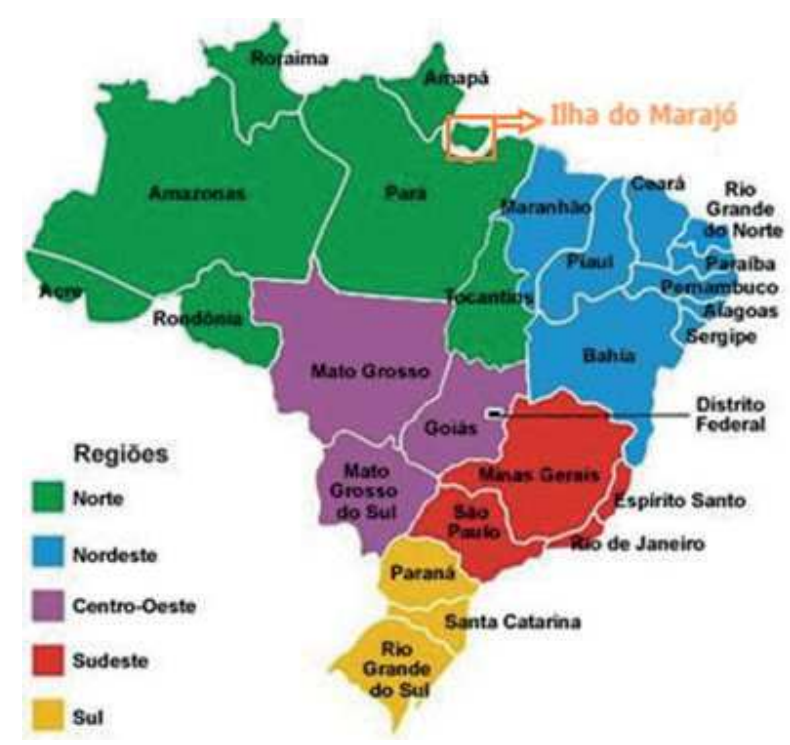

FIGURA 1. Mapa político do Brasil.

FONTE: http://www.espacoeducar.net/2008/02/atlas_08.html.

\footnotetext{
${ }^{1}$ Essa lei institui o Sistema Nacional de Unidades de Conservação (SNUC).
} 
No dia cinco de junho de 2006, após quase dez anos de luta, o Estado Brasileiro atendeu a reivindicação pela criação da RESEX no Alto Rio Canaticú, reconhecendo tanto a importância ambiental e ecológica desse território ${ }^{2}$ quanto o seu caráter tradicional, ou seja, um espaço necessário à reprodução cultural, social e econômica de povos e comunidades tradicionais (Brasil, 2007). O Decreto Federal $n^{\circ}$ 6040/2007, em seu Art. 3o, define estes povos e comunidades como:
Grupos culturalmente diferenciados e que se reconhecem como tais, que possuem formas próprias de organização social, que ocupam e usam territórios e recursos naturais como condição para sua reprodução cultural, social, religiosa, ancestral e econômica, utilizando conhecimentos, inovações e práticas gerados e transmitidos pela tradição (Brasil, 2007).

Pode-se verificar, assim, que as ocupações tradicionais são elementos importantes na caracterização desta população. Essa categoria, "populações

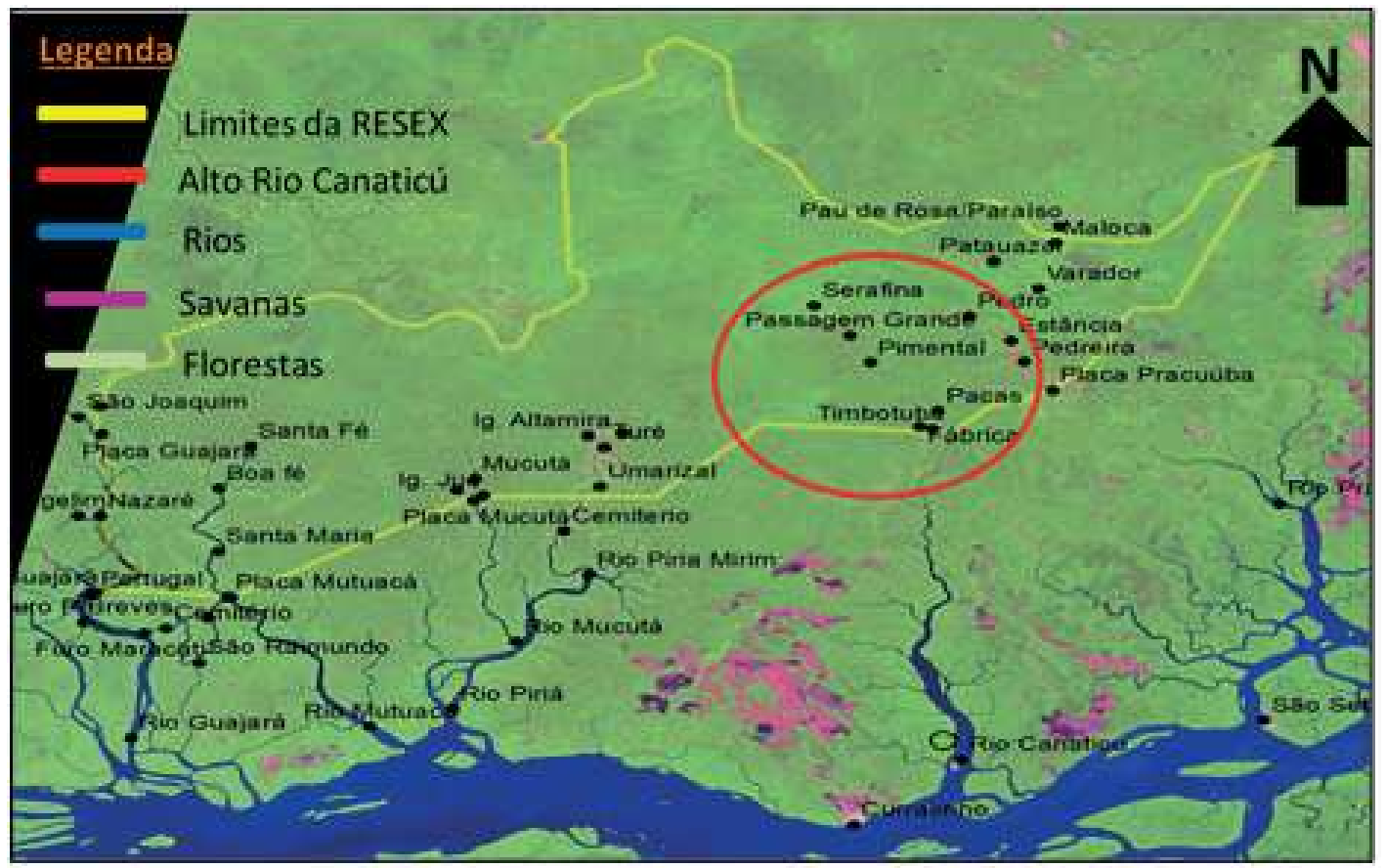

FIGURA 2 - Mapa da RESEX com a identificação das comunidades, rios, centros urbanos dos municípios de Curralinho e São Sebastião da Boa Vista e a fábrica de extração e beneficiamento de palmito.

2 “O território não é apenas o conjunto dos sistemas naturais e de sistemas de coisas superpostas; o território tem que ser entendido como o território usado, não o território em si. O território usado é o chão mais a identidade. A identidade é o sentimento de pertencer àquilo que nos pertence. O território é o fundamento do trabalho; o lugar da residência, das trocas materiais e espirituais e do exercício da vida" (Santos, 2006, p. 140 apud Silva et al., 2010). 
tradicionais", mais recentemente denominada povos e comunidades tradicionais,

...tem conhecido deslocamentos no seu significado desde 1988, sendo afastada do quadro natural e do domínio dos 'sujeitos biologizados' e sendo cada vez mais acionada para designar agentes sociais, que assim se auto definem, isto é, que manifestam consciência de sua própria condição. Ela designa, deste modo, sujeitos sociais com existência coletiva, incorporando pelo critério político-organizativo uma diversidade de situações correspondentes aos denominados seringueiros, quebradeiras de coco babaçu, quilombolas, ribeirinhos, castanheiros e pescadores que têm se estruturado em movimentos sociais (Almeida, 2006, p. 11 apud Cruz, 2014, p. 66).

Esses povos passam a se proclamar enquanto populações tradicionais no bojo das lutas dos seringueiros do Estado do Acre pelo território que ocupam e, ao mesmo tempo, historicamente associado à defesa da natureza frente ao desmatamento dos seringais para a expansão da monocultura da soja e da pecuária (Cruz, 2014).

A denominação de "povos tradicionais" possibilita uma estratégia nas lutas desses povos em prol de seus direitos, favorecendo suas reivindicações territoriais frente ao Estado brasileiro. Com isso se observa que as diferenças não são somente de nomenclatura, mas têm questões políticas no bojo da discussão, que interferem na forma como essas populações são vistas e tratadas pelo Estado brasileiro.

$\mathrm{Na}$ apresentação das discussões e resultados a seguir, por questões éticas, todos os participantes foram protegidos pelo anonimato, sendo seus nomes substituídos por outros fictícios, garantindo a confidencialidade de seus depoimentos.

\section{Resultados e discussão}

\subsection{Organização socioeconômica das comunidades Timbotuba e Serafina}

Essas duas comunidades são formadas por pessoas que trabalham simultaneamente em diferentes atividades produtivas. O conjunto de saberes necessários à sua formação é criado, transmitido (oral e corporalmente, ou seja, através tanto do discurso quanto do exemplo prático) e recriado através das distintas gerações que vêm ocupando essa região.

Nós criamos nossos filhos, como eu que criei os meus filhos, que meu pai sabe, estão tudo aqui colocado. E todos eles sabem trabalhar, né? Graças a Deus estão livres de estarem fazendo 'gatuagem' pela cidade. Estão livres de estarem se metendo em vício, em mau caminho. Graças a Deus. Isso eu agradeço muito a Deus, a força que Deus me deu: criar meus filhos assim como meu pai nos criou (Dona Josi, 06/06/2016, Timbotuba).

Os extrativistas de açaí na Serafina, em alguns casos também atravessadores ${ }^{3}$ dessa produção que tem fins tanto comerciais quanto de subsistência, em regra não são empregadores de mão de obra assalariada. Além de extrativistas, em geral são

\footnotetext{
${ }^{3}$ Os atravessadores são proprietários e responsáveis pela condução de embarcações utilizadas no intercâmbio de produtos e mercadorias (atravessamento) entre centros urbanos e áreas rurais no estuário marajoara. Assim, se caracterizam enquanto agentes intermediários que tanto compram as produções das comunidades rurais para comercializarem nas fábricas, feiras ou cidades da região; quanto nestas compram mercadorias para venderem àquelas comunidades.
} 
agricultores que produzem a farinha necessária para a subsistência de suas famílias, possuindo também pequenas criações não comerciais de galináceos. Exercem a pesca artesanal e caça para subsistência, assim como exploração e manuseio de recursos madeireiros especialmente para reparos e construções de suas residências e de seus meios de transporte. Alguns poucos membros comunitários agregam a essas a função de servidores públicos junto à prefeitura de Curralinho (agentes de saúde e magistério); ou a ocupação profissional de carpinteiro.

No Timbotuba esse leque ocupacional é mais amplo e diverso, não só no interior de cada 'grupo doméstico', mas também entre estes. Nessa comunidade, é comum os agroextrativistas serem tanto produtores comerciais de açaí quanto de farinha. Em alguns casos, contratam força de trabalho assalariada, ainda que em pequena escala e de maneira intermitente. Alguns, ainda que detentores de pequenas produções de farinha e açaí, negociam $o$ assalariamento de sua força de trabalho junto a outros produtores locais. Assim como na Serafina, alguns 'grupos domésticos' possuem pequenas criações não comerciais de galináceos e exercem tanto a caça quanto a pesca artesanal para subsistência; exploram e manuseiam recursos madeireiros para eventual confecção elou reparos de suas residências e meios de transporte, havendo, neste caso específico, ainda que em pouco número, profissionais da carpintaria que trabalham tanto através de diárias quanto por encomenda. Algumas pessoas somam a essas a ocupação de servidor público municipal (agentes de saúde; merendeiras e faxineiras da escola local e condutores de transporte escolar).
Designamos a formação socioeconômica dos grupos domésticos presentes nas comunidades Serafina e Timbotuba como 'agroextrativista de subsistência e mercantil'. Isso porque as práticas produtivas materiais desses grupos se baseiam na conjugação da agricultura com o extrativismo vegetal (extração de frutos e demais produtos vegetais) e animal (caça e pesca), e, por parte dessas produções, ainda que voltadas em grande parte à subsistência material imediata dos produtores, também estarem inseridas em relações de mercado através da troca ou venda.

Essa designação para as "unidades econômicas de produção e consumo" do Alto Canaticú se aproxima de outra definição presente em estudos marxistas, o da "pequena produção mercanti14". Entretanto, aquela designação será preferida em relação a esta, haja vista que trabalhar com este último conceito traz algumas dificuldades e desconfortos, conforme discorre Duarte (1999, p. 58):

\begin{abstract}
Em primeiro lugar, trata-se de um conceito 'residual que aponta para realidades comumente tratadas como 'secundárias' ou 'marginais', na medida em que sua ocorrência se deu à margem da análise marxista do modo de produção capitalista, designando formas sociais ora anteriores, ora subordinadas, raramente objeto de uma apropriação teórica específica [...] à pouca precisão do conceito junta-se, além do mais, uma grande diversidade empírica de formas ${ }^{5}$ que aqui e ali parecem se aproximar da estrutura básica para que ela aponta.
\end{abstract}

Alguns traços básicos comuns entre a "pequena produção mercantil", conforme descrita por

\footnotetext{
${ }^{4}$ Também designada na literatura como 'produção mercantil simples'.

${ }^{5}$ Entre as quais estão, segundo o próprio Duarte (1999): o 'campesinato', 'artesanato', 'corporação de ofício' e a 'pequena burguesia'.
} 
Duarte (1999, p. 58-59), e o modo de produção ora designado enquanto "agroextrativismo de subsistência e mercantil" são: 1) "modos de produção, naquele sentido mais genérico de uma combinação específica de relações e elementos de um processo de produção imediato"; 2) formações socioeconômicas mercantis, "isto é, de tal forma articulada com outros grupos dentro de uma sociedade mais abrangente"; 3) baseados na noção de propriedade privada dos meios de produção, sendo a posse destes pelos trabalhadores estabelecida através de uma "relação de apropriação real" o surgimento de um não trabalhador; e 5) modos de produção "conviventes com outros e, ao mesmo tempo, diferente - outro".

\subsection{Modos de produzir e coexistir: entre convivências e conflitos}

A comunidade Timbotuba situa-se no alto Rio Canaticú à jusante da comunidade Serafina. Esta está inserida à montante do Timbotuba, numa área que foi a fazenda "Terra Grande", um extenso seringal. $\mathrm{O}$ nome dessa região permanece sendo designado como "Terra Grande" ou "Centro Grande" (mais ao centro, no interior da floresta).

No início da década de noventa do século passado, uma empresa de extração e beneficiamento de palmito chegou ao Alto Rio Canaticú em virtude da compra do antigo seringal. Com o declínio da cadeia produtiva da borracha na região Norte e da cadeia produtiva do palmito no centro-sul do país ${ }^{7}$, a partir da década de sessenta, intensificou-se a explo- ração do palmito do açaí naquela região. Na década de oitenta, o palmito havia se tornado o primeiro produto em quantidade entre os produtos alimentícios extrativos comercializados e industrializados entre os estados amazônicos, e o terceiro em saldo econômico, com o estado do Pará se tornando responsável por $95 \%$ da produção nacional de palmito em conserva (Mourão, 2010).

Características ambientais presentes no território ocupado pela comunidade Timbotuba e distintas das existentes na Serafina favoreceram a instalação da fábrica de beneficiamento de palmito junto àquela. No Timbotuba as terras são altas e não inundáveis, favorecendo a construção das estruturas de alvenaria; e nesse local o rio é navegável e perene o ano inteiro, favorecendo o escoamento de produtos.

Em relação à convivência estabelecida entre os grupos domésticos tradicionais da comunidade Timbotuba e a empresa, destacamos alguns aspectos importantes, tendo por base as similaridades já elencadas entre o modo de produção tradicional sob análise e a "pequena produção mercantil", bem como as análises sobre as formas de convivência dessa com outros modos de produção.

Segundo Duarte (1999), quando tal convivência é estabelecida pelo modo de produção capitalista, quase sempre a relação é caracterizada como de subordinação. Entretanto, com contribuições de Tepicht (1973, p.17 apud Duarte, 1999, p. 60 e 61) Duarte afirma que:

Uma subordinação social nunca pode ter o sentido de uma mera justaposição. Ela afeta fundamentalmente

\footnotetext{
${ }^{6}$ Essa relação denota o controle de quem trabalha tanto sobre o seu processo produtivo quanto sobre os meios de produção e o produzido.

${ }^{7}$ Segundo Mourão (2010), este declínio na região centro-sul ocorreu em função da exploração predatória que as indústrias empreenderam sobre o palmito da palmeira Jussara (Euterpe edulis) e que ocasionou sua quase extinção da mata atlântica.
} 
não só o dominado como também o dominante. "Ora, o modo de produção camponês, tal como o entendemos aqui, não é o gerador de uma formação específica, ele se incrusta em uma série de formações, a elas se adapta, interioriza à sua maneira as leis econômicas de cada uma delas e marca-as por sua vez, cada uma delas, mais ou menos, com a sua presença"» [...] Em cada formação, a cada conjuntura, elas se readequariam, se rearticulariam, no bojo de uma interação 'deformada' e 'deformante'.

Este autor parte dos estudos realizados por Marx em $O$ capital para esclarecer as condições básicas dos fenômenos relacionados à "produção mercantil simples" quando em processos de "subordinação" ao modo de produção capitalista. Esse contexto tenderia a gerar dois tipos de situações: o da expropriação da "produção mercantil simples" ou a sua "diferenciação interna". No primeiro caso, o da tendência à "expropriação", tem-se um processo radical de dissolução pela pressão, quando uma acumulação exterior "fundamenta a liberação dos vendedores de força de trabalho e a pilhagem de seus meios de produção" (Duarte, 1999, p. 62). Esse primeiro caso de pressão capitalista foi o exercido pela empresa de extração e beneficiamento de palmito contra a comunidade Serafina, conforme será descrito e analisado mais adiante.

No segundo caso, da tendência à "diferenciação interna", ou seja, entre as "unidades econômicas de produção e consumo" da "produção mercantil simples"; teríamos um processo internalizado por força da pressão do modo de produção capitalista. Nele, uma "acumulação diferencial" entre essas "unidades" ensejaria que se instaurasse gradativamente a mesma polarização e discrepâncias de concentração de capital baseada em relações entre "proprietários dos meios de produção" e "proprietários da força de trabalho". Neste caso, a formação socioeconômica subordinada assim se manteria em relação ao modo capitalista, tornando-se até mesmo necessária a ele.

Numa análise inicial, a "convivência" estabelecida entre a comunidade Timbotuba e a empresa aparenta ser ou tender a esse segundo tipo. Entretanto, quando nos aprofundamos na análise, é possível perceber que ela se aproxima de "uma outra vertente de diferenciação que corre por conta dos próprios meios de produção envolvidos, ou melhor, do peso com que as características desses meios interferem na reprodução do sistema ou nos ritmos da sua transformação" (Duarte, 1999, p. 62).

Duarte (1999) identifica dois tipos de produção que podem apoiar a análise sobre as convivências entre o modo de produção capitalista e formações socioeconômicas que compartilham traços comuns com a "produção mercantil simples". Essa distinção se refere ao tipo de bem produzido. Caso este bem, ainda que em parte destinado ao mercado, componha também a dieta alimentar dos seus produtores (contribuindo para garantir a reprodução social deles em situação de maior autonomia em relação ao mercado), a convivência com o modelo de produção capitalista tende a se tornar mais flexível, abrangendo situações muito próprias de conformação socioeconômica. Por outro lado, caso o bem produzido pelas "unidades de produção e consumo" não componha a subsistência imediata (especialmente para alimentação) daqueles que o produzem, sendo destinados exclusivamente ao mercado, a tendência é que se comportem sem tanta elasticidade, favorecendo conformações so-

\footnotetext{
${ }^{8}$ Este trecho entre apóstrofes pertencente à Tepicht (1973, p.17 apud Duarte, 1999, p. 60 e 61).
} 
cioeconômicas mais próximas à "subordinação" por pressão do modo capitalista.

A relevância dessa distinção se funda em dois aspectos primordiais. Em primeiro lugar, o fato de uma unidade de produção poder prover a parte de sua subsistência (no sentido de reprodução da força de trabalho) sem a intermediação das relações de mercado lhe garante uma margem de autonomia e flexibilidade que permite o florescimento de uma lógica e de um ritmo muito próprios de adequação [...]Em segundo lugar, a pequena produção de mercadorias destinadas à alimentação parece ter garantida em situações não clássicas de desenvolvimento capitalista (possivelmente em casos marcados pelo ‘capitalismo autoritário', como sugere Velho em sua obra citada) uma área de relevância específica, que é a de manter setores consideráveis da força de trabalho [...] em um regime de produção distinto do dominante mas capaz de funcionar em uma espécie de simbiose secundária e complementar, ao sabor dos booms e crises do sistema econômico dominante (Duarte, 1999, p. 63-64).

O fato dos "grupos domésticos" presentes no Timbotuba se dedicarem a uma produção agroextrativista (com participação complementar de pequenas criações de animais) que se destina em parte ao consumo imediato dos próprios, potencializou o poder de negociação deles frente às propostas apresentadas pela empresa. Isso possibilitou uma convivência distinta da subordinação tanto por "expropriação" quanto por "diferenciação interna", se aproximando mais de um "acordo simbiótico" estabelecido entre agentes que coabitam um mesmo espaço.

‘Acordos simbióticos' entre práticas espaciais no

\footnotetext{
${ }^{9}$ Destaque entre colchetes acrescentado pelo autor.

${ }^{10}$ Proprietário da empresa de extração e beneficiamento de palmito.
}

interior dos quais cada protagonista afigura-se interessado em um certo tipo de 'sucesso' do outro, definido segundo suas próprias razões [e interesses]'. Acordos de tal ordem não resultam, portanto, de uma harmonização dos interesses particulares na submissão a um bem superior, mas de um processo imanente do que Stengers chama de 'entre-captura', onde atores que se 'co-inventam' integram, cada um por sua própria conta, e eventualmente de forma conflitiva, uma referência ao outro (Acselrad, 2004, p. 17).

É comum os agroextrativistas do Timbotuba se referirem à empresa que se instalou no Alto Canaticú como uma alternativa a mais de ocupação e geração de renda, ampliadora de possibilidades e liberdades. E assim parece ter se configurado, porque esses agroextrativistas, pautados na autonomia que possuíam enquanto produtores de sua própria subsistência imediata, apresentavam à empresa a seguinte condição: não trabalhariam nela caso não pudessem manter suas tradições, dentre as quais as ocupações que produziam suas subsistências materiais mais imediatas - para eles, inegociáveis.

Eu mariscava pros meus filhos comerem. Mas quando, eu não deixei o serviço da roça. Eu trabalhava lá, mas quando chegava o verão ia fazer nossa roça[...] Graças a Deus meus filhos nunca choraram com fome de farinha. Farinha sempre, para vender, pagar [...] Não, deixar o nosso serviço? Não. Porque o nosso contrato foi assim, eu disse: 'Seu Vespasiano ${ }^{I 0}$, eu posso vim [...] Porque ele me chamou se eu podia trabalhar lá[...] Eu disse: 'Olha Seu Vespasiano, eu trabalho. De inverno eu trabalho bonito. Mas agora, a semana que eu tirar para capinar a minha roça, eu quero a licença. Mas de verão, eu não vou trabalhar 
efetivo. Porque a semana que a gente tem que plantar de novo[...] eu não venho. Pois é! Aí eu falei para ele que eu não ia largar meu serviço da minha roça porque eu não ia ver meus filhos chorarem com fome. [...] E ai ele concordou comigo. [...] E nunca faltou nada (Josi, 06/06/2016, Timbotuba).

Dessa forma, os agroextrativistas mantinham o livre exercício de suas atividades dentre um conjunto de oportunidades que, a partir da chegada da fábrica, se expandira. Liberdades ou autonomia essas baseadas no controle que continuavam tendo sobre seus meios de produção. Assim, com base num rol de opções que se ampliara, calculavam a melhor distribuição de suas forças de trabalho conforme seus interesses. Enquanto investiam a parte disponível de sua força de trabalho na empresa, agregando assim novas ocupações e poder de compra, mantinham a outra parte de suas forças produtivas direcionadas à desejada estabilidade e segurança advindas da autonomia enquanto produtores diretos dos bens necessários à sua própria subsistência.

Ao depender mais de seu próprio trabalho, enquanto manifestação não de liberdades ou vontades alheias a si, mas sim fruto de sua própria autonomia, o trabalhador tende à sensação de estabilidade e segurança, fatores que contribuem para seu conforto psíquico. Inversamente, quando o trabalhador se coloca em situação de maior dependência às vontades alheias às suas (ou seja, ao depender mais da "sorte" no tocante à sua subsistência material), tende a sofrer com a apreensão e insegurança geradas pela perda de autonomia e controle sobre os meios que lhes garantem parte essencial da subsistência da qual ele e seu núcleo familiar necessitam (Duarte, 1999).
Ao não abdicarem de suas ocupações tradicionais ao distribuírem parte de suas forças laborais na fábrica, os agroextrativistas do Timbotuba parecem terem priorizado seu conforto psíquico ao invés de concentrarem todas suas energias naquilo que detinham pouco ou nenhum controle.

Mas nunca a gente deixou o serviço da roça não. Graças a Deus. Pra que?![...] O meu pai ele disse: 'Quando a cabeça não pensa, o corpo padece. Portanto nós devemos pensar primeiro com a cabeça pra poder enfrentar, meter a cara pra fazer [...] E portanto eu pensei com a cabeça. Eu trabalhei na fábrica, mas eu nunca deixei meu plantio, meu trabalho. Eu nunca deixei de criar minhas criações, meus 'seribabos', minhas galinhas. Até hoje eu crio, com o maior sacrificio, eu crio[...] Porque o senhor sabe que uma coisa dessa (se referindo à fábrica que ali se instalou) não é de raiz. E onde você tá colocado, que você tá com seu trabalho[...] é de raiz! Porque uma fábrica dessa, como ele (dono da fábrica) veio de lá, comprou essa área aí, sentou essa fábrica. Olha ele tinha vontade de sentar polpa de açai aí. Ele tinha vontade sentar coisa de cacau. Ele tinha vontade de sentar fábrica de urucum. Mas não foi. Como era que a gente ia tudo largar do serviço daqui para trabalhar lá e depois, de repente, alevantava? (Dona Josi, 06/06/2016, Timbotuba).

Não obstante o acima evidenciado, é importante lembrar que os "acordos simbióticos" firmados entre os agroextrativistas do Timbotuba e a empresa deram-se num contexto de discrepâncias entre os mesmos. A empresa trazia algumas tecnologias (meios de produção) com ela e que, devido ao baixo poder de compra dos agroextrativistas, não eram acessíveis a eles. Para extrair palmito do 'Centro Grande', a empresa “tinha motor. Era barco. $\mathrm{Na}$ 
época do inverno iam embora de barco[...] A empresa tinha dois barcos" (Fátima, 06/06/2016, Timbotuba). Já o agroextrativista, "ele tinha um casco[...] Não pegava mil palmitos[...] E eles tinham que ir remando" enquanto os barcos da empresa, em cada viagem, pegavam "três mil, cinco mil" (Fátima, 06/06/2016, Timbotuba).

Na época[...] já tinha esse motor sim, mas por aqui não tinha porque ninguém tinha condição era de comprar. Ai era remo mesmo. Tinha vez que saía daqui de manhã cedinho e ia chegar à tarde para lá, para esse lugar de onde ele trazia (o palmito). Ele morava lá (na Terra Grande) e aí depois a gente veio para cá (no Timbotuba). Ai ele continuava trabalhando para lá porque aqui não tinha serviço pra ele. Porque a roça a gente faz, mas só colhe pro outro ano, né?[...] E tinha que trabalhar em outros trabalhos pra se manter até a roça amadurecer (Fátima, 06/06/2016, Timbotuba).

Além das embarcações motorizadas, a empresa também chegou a transportar o palmito extraído da "Terra Grande" por ar e terra. Durante um período, utilizaram helicóptero e também abriram, com apoio estatal,

... a estrada que ia pro Pimental: Timbotuba-Pimental. Essa estrada, no tempo do Agnelo, do Acapú, ela era registrada. Vinha uma verba especialmente pra fazer a limpeza dela todo ano. Eai eles esbandalharam a estrada. Hoje, a estrada está aí no cerrado[...] Recurso da prefeitura para essa estrada[...] vinha. Antigamente tinha[...] Já tinham parado com helicóptero, estavam com caminhão (Josias, 09/06/2016, Serafina).
Como se verifica acima, a atuação estatal muitas vezes não se limita a reconhecer e legitimar os agentes capitalistas que, no Mapa dos Conflitos Ambientais ${ }^{11}$, são apresentados como agressores. Mais que isso, quando não atua diretamente com eles, frequentemente os subvenciona (Pacheco \& Faustino, 2013), contribuindo para a manutenção e até mesmo a acentuação de desigualdades históricas.

Assim, diferentemente dos agroextrativistas, além dos meios e tecnologias (muitos dos quais subsidiados pelo Estado) que otimizavam a extração de palmito, a empresa detinha uma concentração de capital que a permitia ser também beneficiadora do produto. Para tanto, necessitava ofertar empregos para conseguir a força de trabalho necessária à sua atividade econômica. Desta forma, apesar da consciência que os agroextrativistas do Timbotuba tinham da exploração sobre seus corpos e força de trabalho, a fábrica representava uma oportunidade de incremento para seus limitados poderes de compra. Para Acselrad (2004, p. 17), quando acordos simbióticos são estabelecidos entre agentes com interesses sobre um mesmo território, aqueles se dão "no interior de inescapáveis relações de poder".

Ao não terem meios suficientes para a produção necessária tanto à subsistência quanto à qualidade de vida que almejavam, os agroextrativistas do Timbotuba perdiam em poder de pressão e negociação das condições de trabalho precárias oferecidas por quem detinha esses meios: a empresa. Em um panorama contrário, com relação à oferta de empregos e investimentos no local, os 'grupos domésticos' do Timbotuba poderiam avaliar que

\footnotetext{
${ }^{11}$ Iniciativa que visa - através da sistematização de informações e a listagem de territórios onde riscos e impactos ambientais afetam diferentes populações brasileiras - tornar públicas as vozes que lutam por justiça ambiental e que frequentemente são discriminadas e invisibilizadas pelas instituições e pela mídia: http://www.conflitoambiental.icict.fiocruz.br/
} 
na empresa não compensaria trabalhar, incluindo eventual recusa quanto à sua instalação em seu território caso entendessem que o bônus que teriam seria menor que o ônus econômico e socioambiental.

Diferente da comunidade Timbotuba, a comunidade Serafina gerou forte resistência à entrada da empresa na região:

Ai ele entrou. Entrou para cá e fazendo proposta com nós. Queria que a gente ficasse com um pedacinho de terra e ai ele tomasse conta do resto para terminar. Acabar com o que tinha, sabe? Aí nós não consentimos, eu e a Domingas, minha filha, nós não consentimos, sabe? A gente sempre debatia com ele. Os outros já estavam tudo caindo na malha dele, mas nós não consentimos. Aí nós ficamos duras mesmo com ele. Ele vinha para cá e a gente teimava com ele. Ai ele começou com perseguição para cima de nós (Dona Conceição, 76 anos, 11/06/2016, Serafina).

A empresa ameaçava a manutenção das áreas de produção e dos bens naturais necessários à sobrevivência da comunidade Serafina, ou seja, a conservação de seu território tradicional. Os agroextrativistas do Timbotuba compartilhavam da mesma preocupação que os da Serafina em relação à conservação de seu próprio território tradicional. No entanto, a preocupação daqueles foi remediada quando os bens naturais de que dependiam para sua subsistência foram resguardados da exploração capitalista.

Trabalhei, eu passava Palmito. Nós tínhamos um barquinho. Ai a gente passava palmito ai pra ele (Dono da empresa) [...] Mas pedindo a Deus que a Serafina ganhasse a questão. Porque a hora que ele afetasse eles lá, ele ia afetar nós aqui. Porque a gente estava mais perto dele. Ai ele chamou a gente pra um acordo. [...] O Vespasiano: 'Olha, eu vou fazer com vocês o seguinte, eu comprei toda a terra, comprei aqui, comprei pra aí, comprei Terra Grande, é tudo minha. Agora eu quero aqui mesmo. Eu quero esse lugar para fazer a fábrica [...] E eu quero perguntar para vocês até onde vocês trabalham, aqui no terreno? ' [...] Ai ficamos com três lotes de terra (Genival, nasceu em 1966, 07/06/2016, Timbotuba).

Uma característica ambiental do território tradicional da comunidade Timbotuba contribuiu para que este não fosse almejado pela empresa. $\mathrm{O}$ foco de exploração dessa era o palmito de açaizeiros “que não tinha quase aqui nessa beirada” (Maria, 07/06/2016, Timbotuba). Já na Serafina, extensas áreas naturais de açaizais eram encontradas nas várzeas que compunham o território tradicional dessa comunidade.

Ai ele queria acabar com as nossas áreas de produção, que eram os açaizais, os seringais. Ai já entrou a Remonorte, que entrou para tirar madeira. Ele arrendou[...] Eu sei que ele fechou com a Remonorte para tirar madeira, e ele tirava o palmito. E ai nós não queríamos. Nós brigamos por causa disso! Por causa da produção do açaí, e a seringa também. Ai a seringa parou, a borracha parou, né? Ai ficou só no açaí (Chico, 10/06/2016, Serafina).

Ainda que existissem alguns açaizais plantados no Timbotuba, ou mesmo alguns pequenos 'bancos' naturais localizados em extensões menores de áreas que sofriam inundação, a empresa nelas não interferia:

Na verdade, (açaí) aqui é só no sitio mesmo. Por aqui, no mato ai mesmo, ele (dono da empresa) não mexia com isso. Ele queria tirar ai do 'Centro Grande'. [...] Só que ia acabar com o pessoal lá de cima, né? Por isso que eles começaram a briga deles lá (Genival, 
nascido em 1966, 07/06/2016, Timbotuba).

Mantidos os açaizais e as demais áreas necessárias às ocupações tradicionais da comunidade Timbotuba, entre elas os roçados, não se constituiu uma disputa por recursos naturais entre essa comunidade e a empresa. Com isso, não havia possibilidade da deflagração de um conflito ambiental entre esses, tal como se deu entre a empresa e a comunidade Serafina. Lideranças agroextrativistas dessa também corroboram esse entendimento: " $A s$ pessoas que trabalhavam pra empresa de lá, eles não foram afetados. Eles não foram afetados, sabe por quê? Por isso que eles apoiavam ela, afetados como? Na área deles" (Renata, 09/06/2016, Serafina).

Não obstante, vale ressaltar que alguns moradores da comunidade Timbotuba, à época da chegada da empresa, subiam até o 'Centro Grande' para extrair o mesmo produto que aquela almejava: "Nessa época aqui era até mais dificil. Porque meu pai ele trabalhava[...] Tinha as vezes que ia fazer a roça dele, mas tinha vezes ia lá pro Centro[...] pra cortar o palmito. Vinha de lá, vendia "(Fátima, 06/06/2016, Timbotuba).

Antes da fábrica. Ai ele vendia para esses regatões que nem hoje em dia passa. Só que hoje é comprando açaí, né? Na época eles compravam açaí, eles compravam palmito. Aí quando não tinha o açaí, tinha vez que ele cortava o palmito e trazia pra eles (Fátima, 06/06/2016, Timbotuba).

Ainda que a manutenção das áreas de produção localizadas no Timbotuba estivesse acordada com a empresa, a exploração intensiva de palmito exercida por aquela na "Terra Grande" ameaçava áreas e recursos que eram explorados não só pelos moradores da Serafina, mas também pelos agroextrativistas daquela outra comunidade. Se agroextrativistas tanto do Timbotuba quanto da Serafina utilizavam e dependiam dos açaizeiros quando da chegada da fábrica, quais outras razões teriam contribuído para aqueles não terem entrado em conflito com a empresa?

Explicitamos aqui como as discrepâncias de capital e consequente desigualdade de poder sobre meios adequados e suficientes de produção, existentes entre a comunidade Timbotuba e a empresa, favoreceram a atividade exploratória de corpos e predatória do território e seus recursos naturais por parte do grande capital.

Um fator de diferença entre o trabalho dos agroextrativistas do Timbotuba e da Serafina na exploração dos açaizais era que, para acessá-los, os primeiros dependiam de um dispêndio de energia - força de trabalho - maior do que os segundos: os agroextrativistas do Timbotuba tinham que subir remando pelo rio até chegarem aos açaizais da 'Terra Grande'.

Hoje em dia a gente tem esse motor rabudo, que põe gasolina e quando está bom vai embora; e na época era a remo mesmo[...] Tinha vez que eles chegavam a remo meia noite, uma hora, né? Apanhavam chuva, apanhavam o que tivesse no rio e tinham que chegar. E a remo, né? Por isso que digo que era mais dificuldade para eles, né? (Fátima, 06/06/2016, Timbotuba).

As maiores exigências e necessidades de meios de produção por parte da comunidade Timbotuba à época - enquanto tecnologias e ferramentas que mitigassem as dificuldades impostas pelas maiores distâncias a serem percorridas para a exploração 
econômica de açaizais - parecem ter sido outro fator que favoreceu a articulação de interesses comuns entre essa comunidade e a empresa, que detinha embarcações motorizadas para aquele deslocamento. Isso contribuiu para sua implantação e operação no território.

\subsection{Territórios materiais e simbólicos: modos distintos de ocupá-los}

Dentre as práticas tradicionais analisadas, tanto o manejo e extração do açaí quanto a roça e produção da farinha se caracterizam por uma dupla função em relação à satisfação das necessidades materiais dos agroextrativistas. Ao mesmo tempo em que parte dessas produções é consumida diretamente por seus produtores, compondo a base alimentar dos grupos domésticos locais, a outra parte é vendida e/ou trocada no mercado. Alguns bens que os agroextrativistas necessitam e/ou desejam (entre os quais itens de limpeza, higiene pessoal, complementos alimentares, vestuário, eletrônicos e eletrodomésticos) não são produzidos pelos próprios, sendo importante o estabelecimento de relações comerciais para tais aquisições.

Entretanto, existem diversas ocupações que estão voltadas exclusivamente à produção da subsistência material imediata das famílias, não sendo realizadas, nem em parte, com fins comerciais. Entre elas estão a pesca artesanal, a pequena criação de animais e a caça. Quanto à quantidade e disponibilidade desta,

Carlos: ainda tem ainda[...]

Tobias: Tem um mucado ainda. Aqui na beira do rio a gente não mata assim mais por causa do barulho, que são muitos os 'rabudos'.
Carlos: Muito motor à noite funcionando, pra todo lado, né?

Tobias: Aqui por perto assim mesmo, né? Pra longe mesmo, anoiteceu a gente tá matando caça (Carlos e Tobias, 07/06/2016, Timbotuba).

Neste caso, agroextrativistas não registram diminuição da oferta ou da disponibilidade de caça. A escassez que ocorre atualmente - e restrita às áreas próximas às comunidades - é atribuída não a eventuais diminuições da quantidade de animais, mas sim ao ingresso e funcionamento dos ruidosos motores utilizados tanto no transporte fluvial antes realizado a remo - quanto nos geradores de energia elétrica. Atualmente, cada "grupo doméstico" possui seu próprio grupo gerador. Estes são ligados ao anoitecer para fornecer luz elétrica e energia à televisores, aparelhos de som, geladeiras/ congeladores e baterias dos aparelhos celulares dos agroextrativistas.

Essas recentes mudanças socioeconômicas também promoveram mudanças no acesso aos mercados. Aqueles que possuem qualificações e acesso a ocupações que propiciam maiores ganhos financeiros, eventualmente preferem abrir mão de caçar em períodos e épocas menos propícias para investir mais tempo no aumento de seu poder de compra. É o caso de um carpinteiro profissional local:

Eu não me preocupo mais com isso aqui. Eu prefiro trabalhar de segunda à sexta pra ganhar o dinheiro, passar o marreteiro, eu comprar. Do que eu empatar meu tempo: eu ir lá no mato, pra ver se eu mato uma paca, um tatu de dia. Eu não faço isso. Não tem como, a gente não acha. Agora de noite talvez. Quando a gente sai assim na época do verão, da 'flor do piquiá', a gente mata (Zuenir, 39 anos, 08/06/2016, Timbotuba). 
A resistência daqueles que não abrem mão em manter a tradição de caçar não está associada somente às necessidades de subsistência material: satisfações culturais também estão envolvidas com o exercício de tal prática na medida em que, a partir dela, se distinguem e auto-afirmam socialmente:

Tobias: No interior, se o cara escuta tiro, é caça; na cidade [...] Carlos: É um que morreu, já (risadas) (Carlos e Tobias, 07/06/2016, Timbotuba).

A prática da caça tradicional se relaciona também com a satisfação de necessidades afetivas, de sociabilidade e de lazer: certa ocasião, mesmo eu tendo levado suprimentos para o almoço e o jantar junto ao 'grupo doméstico' do agroextrativista que entrevistava, este "me convidou pra caçar com ele, 'lanternar'” (Notas do Diário de Campo, 07/06/2016, p.22). Em outra situação, quando dois jovens conversavam sobre o que fariam para se distrair ao fim do dia, a caçada surgiu ao lado do futebol:

Saulo: "E aí, nós vamos lanternar?"

Eliel: "Com quem tu falou?"

Saulo: "Com ' $X$ ', 'Y'. E aí, a bola?" (Saulo e Eliel, 09/06/2016, Serafina).

Da mesma forma que a caça se configura como uma ocupação que integra e supre diferentes necessidades, não se restringindo às de base material, a pesca se apresenta de maneira semelhante. Quando perguntei a uma agroextrativista, que conjuga seus afazeres domésticos e da roça com a de merendeira, o que ela gostaria de estar fazendo caso não tivesse que trabalhar na escola local:

Aí eu ia estar só no rio pescando, que eu gosto. Eu gosto muito. Assim, quando chega ao periodo de férias, que minhas irmãs vêm de Belém, ai não tem a escola, não tem aula, né? Aí a gente pesca muito. Sai pro rio pra pescar. Todo mundo, de canoa, no casco, né? Aí vão duas em cada casco. Vai conversando, leva garrafa de café, leva comida no marmitex, assim vai pescar. Chega só de tarde. Isso pra nós é uma diversão (Sofia, 07/06/2016, Timbotuba).

A produção da farinha de mandioca nas 'casas de forno' e a extração e comercialização do açaí são outros exemplos da indissociabilidade entre as satisfações materiais e imateriais no fazer tradicional.

\begin{abstract}
Porque o açai é assim: Se tu consegue criar uma amizade com o pessoal - tanto com o extrativista quanto com as batedeiras - se tu consegue criar uma amizade com eles, tu não sabe sair mais daquilo. $\dot{E}$ o mesmo que um vício de droga. Porque nem que tu ache outro meio de estar trabalhando, mas aquilo ali deixa uma saudade. Porque é o contato fisico, né? O contato com as pessoas. Olha, eu estou nessa situação de saúde, mas eu não consigo ficar assim sem tá trabalhando com o açaí, com as pessoas. Que tu chega lá, tu está brincando. Tu está é, Ah! É fora de série! Muito bom! Dá um pouco de sacrificio pra ti estar te sacrificando, mas quando tu chega na feira, tem aquela energia positiva. Aquela energia de tu estares brincando com as pessoas. É muito bom. Assim são eles (atravessadores) com os peconheiros ${ }^{12}$, né? [...] Ai é papagaiada. É conversa pra lá, conversa pra ali. Embarca um açai e outro pra ali. Isso aí vai dando uma alegria, um costume. Um costume que tu pega (Chico, 10/06/2016, Serafina,).
\end{abstract}

\footnotetext{
${ }^{12}$ Denominação comumente utilizada na região para designar os trabalhadores que extraem açaí. Esta designação advém da peconha, pedaço de tecido que os peconheiros trançam nos pés para subir nos açaizeiros e extrair os frutos de açaí.
} 
Ainda que em muitas dessas práticas a diversão, a construção de laços sociais e afetos, assim como a autoafirmação e a distinção social não estejam desatreladas da busca pela subsistência material, esta continua sendo fator fundamental de mobilização para o agir transformador no mundo: "Eu à tarde assim, eu sempre saio pra pescar" (Sofia, 07/06/2016, Timbotuba).

Primeiro porque a gente gosta do peixe daqui, da maré, né? A gente acha gostoso. E depois porque a gente precisa, né? Porque nem todas às vezes a gente tem condição de estar todo dia comprando, né? Porque a gente ganha pouco. O Zuenir tem esse trabalho dele que ele ganha assim quando ele faz uma rabeta. Ai quando ele não faz, não tem como ganhar, né? (Sofia, 07/06/2016, Timbotuba).

É possível evidenciarmos que as práticas tradicionais são trabalhos significantes e produtores de patrimônio tanto material quanto imaterial, caracterizando-se desta forma, conforme entendimento de Costa (2012) e Alvarenga \& Costa (2016), enquanto ocupações tradicionais. Compreender estas, ou em outros termos, compreender os modos de ser sujeito nas relações que engendram o trabalho, segundo Veronese \& Guareschi (2005), é um tema muito caro à psicologia social crítica, haja vista ser o labor

[...] espaço privilegiado de constituição do sujeito, entendendo este último como resultado de processos de construção simbólica de sentido. Os processos sempre relacionais que envolvem o trabalho, que o engendram e a partir dos quais se forjam outras relações e experiências, podem assumir configurações peculiares. Todas elas, entretanto, vão ser constitutivas da vida das coletividades que abrigam os sujeitos individuais - a consciência de si que chamamos de "eu" - e destes próprios, como alguém que age sobre o mundo para apreendê-lo. (Veronese \& Guareschi, 2005, p. 58).

Em diversos estudos sobre a classe trabalhadora, há menções sobre a oposição existente entre as categorias "trabalho" e "sorte". Entretanto, diferentemente do proposto nesses estudos mencionados por Duarte (1999), em sua pesquisa junto aos pescadores de Jurujuba, esse autor propõe que esse par de categorias deixe "de significar a oposição entre o sentido do interior e do sentido exterior da comunidade para expressar o sentido do interior e o sentido do exterior de cada prática "individualizada" (Duarte, 1999, p. 97 e 98). Nessa perspectiva, essas categorias ganham contornos enquanto processos psicológicos engendrados na prática laboral.

As flutuações do mercado no Alto Canaticú interferem no sucesso do trabalho daqueles agroextrativistas que dependem da sorte em relação às condições mercantis sobre as quais não possuem governança, como é o caso da demanda pelos seus produtos: "tem esse trabalho dele que ele ganha assim quando ele faz uma rabeta. Ai quando ele não faz, ai não tem como ganhar, né?" (Sofia, 07/06/2016, Timbotuba). Almejando segurança e estabilidade, tanto material quanto emocional, o agroextrativista-carpinteiro, ainda que venda sua força de trabalho ou o produto dela: "Mas ai eu não deixo de fazer a minha roça, fazer o meu açaizal. Porque se eu for trabalhar na canoa direto, eu já vou perder a minha roça, perder o meu açaizal" (Zuenir, 39 anos, 05/06/2016, Timbotuba).

Os desejos por segurança e estabilidade, ainda que inicialmente individuais, se refletem na configuração socioeconômica tanto da comunidade Timbotuba quanto da Serafina, bem como nas relações destas com o mercado. Tais grupos 
tradicionais estabelecem relações mercantis sem se desfazerem de profundas e fortes "raízes" que lhes proporcionam aquela almejada estabilidade: as práticas tradicionais de produção imediata de sua subsistência, como é o caso das roças de mandioca e o preparo de açaizais. E raízes precisam da terra para ancorarem-se.

Assim aconteceu quando grupos domésticos da comunidade Timbotuba, ao negociarem a instalação e o funcionamento da fábrica de extração e beneficiamento de palmito em seu território, condicionaram tal implantação ao não comprometimento de suas áreas de produção e de seu trabalho nos açaizais, roçados e criações de pequenos animais. E também aconteceu na Serafina, quando, unidos por conta da ameaça externa representada pela empresa, recusaram os riscos do imponderável - representado pela dependência a um trabalho assalariado - em prol da segurança e estabilidade representada pelo controle sobre seus próprios meios de produção e, consequentemente, sobre suas próprias vidas.

Para as comunidades pesquisadas, a desejável e necessária abertura ao mercado significa também se submeter às flutuações deste. Estas flutuações, além de poderem ocorrer em virtude de condições circunstanciais do próprio mercado, também podem surgir em virtude de condições ambientais circunstanciais ou mesmo periódicas e recorrentes, como acontece na Serafina quando chega o período do inverno $^{13} \mathrm{e}$ as chuvas diminuem. Nesta época continua havendo demanda do mercado pela produção local de açaí. As necessidades dos 'grupos domésticos' da comunidade em comprar bens de consumo junto ao mercado, em geral intermediada por atravessadores, também se mantém. Entretanto, a falta de condições de navegabilidade nas cabeceiras do Rio Canaticú onde a Serafina se localiza - impõe um isolamento a esta comunidade, restringindo a manutenção de suas relações comerciais no período de "estiagem":

No verão não tinha trabalho pra gente pra cá. Olha, era só na roça mesmo. Tinha que trabalhar igual saúva. Trabalhar no inverno pra comer no verão. Só dá roça mesmo. Só pra comer. (O açaí) só para o consumo da gente mesmo (Orlando, 09/06/2016, Serafina).

Este isolamento é hoje parcialmente mitigado pela limpeza que os agroextrativistas realizam em uma estrada que conecta a Serafina à comunidade Pimental, por onde se trafega de bicicleta. Assim, ainda que permaneçam as limitações de escoamento da produção de açaí, os agroextrativistas conseguem fazer algumas viagens esporádicas à cidade para comprar alguns bens que necessitam. Não obstante, tal ação apenas mitiga os efeitos deste isolamento, posto que 1) a capacidade de carga de uma bicicleta nessas condições, em viagens de mais de uma hora, são limitadas; e 2) o poder de compra das famílias da Serafina neste período fica comprometido, tendo em vista a impossibilidade de escoamento e venda de suas produções de açaí.

Em tais condições, explicita-se a importância, para esses grupos tradicionais, de ocuparem um território que mantém condições ecossistêmicas de suprir suas necessidades de subsistência. As raízes ou práticas tradicionais, além de terra para ancorarem-se e proporcionarem a estabilidade que delas se espera, precisam de um terreno fértil, que mantenha

\footnotetext{
${ }^{13}$ No estado do Pará o inverno é denominado de verão, e este de inverno. O período de inverno é caracterizado pela diminuição no volume das chuvas e ocorre aproximadamente entre os meses de junho a novembro.
} 
condições de fornecer os materiais/nutrientes a serem transformados e usufruídos. Quando as relações com o mercado ficam impossibilitadas pela falta de condições de navegabilidade nas cabeceiras do Rio Canaticú, a fartura de peixe contribui para que os agroextrativistas da Serafina se mantenham: "Tinha muito nessa época. Tinha. No verão é que dava peixe mesmo. Ficam uns lagos grandes aqui nesse igarapé. Não seca tudo não. Seca assim pra não vim rabeta, mas pra dizer que não fica água, fica" (Orlando, 09/06/2016, Serafina).

Ainda que as relações com o mercado apresentem flutuações, a conservação das relações ecossistêmicas de seus territórios garante a esses povos tradicionais uma segurança material mínima. O controle sobre conhecimentos e meios para sua subsistência (material e imaterial) lhes garante uma relativa margem de segurança e autonomia sobre o curso de suas vidas.

Em caráter hipotético, caso o modo tradicional de exploração do açaí, de construção e funcionamento de suas vilas ou da agricultura tradicional impactasse de maneira crítica a disponibilidade de peixes ou de caça em seus territórios, direta ou indiretamente, não seria apenas um ecossistema que estaria sendo comprometido: seria também a reprodução de ocupações geradoras tanto de subsistência material quanto imaterial para tais povos tradicionais. Entre as imateriais, a produção de bem estar e saúde emocional proporcionada no lazer e na sociabilidade; assim como a produção de auto-reconhecimento e autoestima advindas da distinção social. Produções imateriais estas que são, tanto quanto às materiais, mediadas pelas prá- ticas tradicionais de subsistência. Assim, caso tais práticas venham a comprometer de maneira crítica o equilíbrio do ecossistema que esses povos tradicionais ocupam, antes de qualquer outra sociedade, seria a própria reprodução social deles que ficaria comprometida.

Além disso, ao manterem relações de exploração material - que produzem alimentos, moradia, vínculos familiares e sócio-afetivos, memórias, lazer, autor-reconhecimento, autoestima e demais usufrutos - diretamente junto ao território que ocupam, baseiam-se materialmente de modo diverso das concepções e formas de desenvolvimento atualmente hegemônicas. Desta forma, quanto à relação desses povos com os ecossistemas (a dimensão ambiental), uma distinção entre o atual modelo hegemônico de desenvolvimento e o modelo dos povos tradicionais é o fato das atividades econômi$\operatorname{cas}^{14}$ destes não estarem descoladas espacialmente das demais ocupações voltadas à sua reprodução social: "Josias brinca com a criançada demais: sobem no segundo andar e pulam no rio, brincam de queimada no campo quando os 'velhos' estão fazendo farinha" (Notas do Diário de Campo, 10/06/2016, p.45).

Quando práticas econômicas de determinada sociedade são deslocadas de seu próprio território para serem alocadas em territórios de outras sociedades ou em espaços não ocupados e significados, tal deslocamento comumente resulta em desequilíbrios ambientais, que por si só são também sociais. Segundo Leroy \& Meireles (2013), o espaço se torna algo indefinido, mero suporte para atividades econômicas e infra-estruturais, sendo esta uma caracte-

\footnotetext{
${ }^{14}$ Aqui entendidas como os trabalhos que visam ou respondem a alguma demanda mediatizada pelo mercado, ou seja, que visem a venda ou troca do que é produzido. No caso desses povos e comunidades tradicionais coincidem com atividades de subsistência por também propiciarem diretamente parte considerável de suas necessidades materiais.
} 
rística das concepções e formas de desenvolvimento capitalistas, atualmente hegemônicas. Essa busca por um crescimento baseado no uso intensivo dos recursos naturais tende a resultar em esgotamento e degradação social e ecossistêmica.

Quando essas perturbações se fazem presentes em espaços ocupados, o movimento por justiça ambiental as caracteriza enquanto injustiça ambiental. Este tipo de injustiça ocorre quando "se destina a maior carga dos danos ambientais a grupos sociais de trabalhadores ou grupos étnicos discriminados[...] ameaçando a integridade da saúde ambiental e comprometendo a sua reprodução social" (Loureiro \& Layrargues, 2013, p. 63).

Entendemos por injustiça ambiental o mecanismo pelo qual sociedades desiguais, do ponto de vista econômico e social, destinam a maior carga dos danos ambientais do desenvolvimento às populações de baixa renda, aos grupos raciais discriminados, aos povos étnicos tradicionais [...] (Rede Brasileira de Injustiça Ambiental, apud Leroy \& Meireles, 2013, p. 119)

Foi contra tal injustiça que as comunidades tradicionais da Terra Grande lutaram quando a empresa de extração e beneficiamento de palmito instalou-se em seus territórios para explorá-lo economicamente. $\mathrm{O}$ dono dessa empresa, que não residia na Terra Grande, deslocou suas ocupações econômicas a este território tradicional e manteve as demais ocupações e relações necessárias à sua própria reprodução social distantes do local. Eventuais impactos negativos gerados pela busca em maximizar os lucros da empresa, desde que não afetassem de imediato esses ganhos de capital, não afetavam a reprodução social daquele que promovia tais atividades produtivas; atingem, porém, a reprodução social daqueles que ocupavam tradicionalmente $o$ território explorado.

Ocupação, entendida como direito social, é aquela que, individualmente ou coletivamente, significa e produz significado social. Dessa forma, a expressão ocupação tradicional é tratada como prática significante e produtora de patrimônio (material e imaterial), caracterizada pelo trabalho como mediador entre o ser humano e a natureza (Costa, 2012, p. 44).

O mencionado significado social da ocupação tradicional, segundo Costa \& Macedo (2016), tem características locais. Com base nos conhecimentos locais, as atividades cotidianas e a ocupação do espaço neste promovem transformações, transformando-o também em lugar de pertencimento. (Costa \& Macedo, 2016, p. 237). Desta forma, "ao criarem lugares, as atividades também fazem as pessoas serem daqueles lugares" (Prado, 2012, p.187, apud Costa \& Macedo, 2016, p. 237):

Sempre nós defendemos do Jijú para cá, que é a Terra Grande. Timbotuba é uma área a parte; Pacas é uma área a parte [...] Então de lá para cá era (e continua sendo) dos moradores daqui. Nós sempre defendemos. O que tem lá dentro é nosso, mas nosso, de quem mora, que tem direito de usufruir dessa área (Josias, 09/06/2016, Serafina).

Quando "as pessoas pertencem às localidades e ambientes em que cresceram, tanto quanto estes pertencem a elas" (Ingold \& Kuttrila, 2000, p. 195, apud Costa \& Macedo, 2016, p. 236), essas pessoas tendem a preservar esses espaços, a conservá-los enquanto locais que lhes proporcionam abrigo e aconchego. Quando, nesses espaços, têm-se um sistema ecológico a partir do qual as práticas sociais de 
subsistência se constituem em estreita interdependência, fundamentam-se "ancestralidades e vínculos interdependentes com a conservação dos biomas e ecossistemas" (Leroy \& Meireles, 2013, p. 117).

Ocupando tradicionalmente os territórios, os povos e comunidades tradicionais sentem, compreendem, agem e reagem conforme as demandas do contexto natural onde se inserem, a fim de continuar propiciando as condições necessárias à sua subsistência.

Nesse sentido, não obstante a vitalidade dos ecossistemas ser necessária aos seres humanos em geral, a proteção e recuperação ambiental aparecem como imprescindíveis especialmente para a garantia dos modos de vida dos povos e comunidades tradicionais (Porto \& Pacheco, 2009 apud Pacheco \& Faustino, 2013). Ao terem seus territórios-ecossistemas resguardados e conservados em sua integridade, tais comunidades garantem sua "qualidade de vida, suas práticas culturais e econômicas solidárias e a própria biodiversidade" (Leroy \& Meireles, 2013, p.122). "Que ai saiu o coisa para criar uma reserva[...] Se é que resolvia o problema da população, vamos criar uma reserva" (Josias, 09/06/2016, Serafina).

Em meio à intensa luta, inclusive judicial, e articulações junto à movimentos sociais e entidades sindicais, o processo formal de criação da RESEX Terra Grande-Paracuúba se iniciou em 1997 através de ofício encaminhado pela Associação de Produtores Rurais de Curralinho ao IBAMA. Junto ao ofício foi enviado um abaixo-assinado de moradores e declarações de diversas instituições públicas e organizações da sociedade civil solicitando e declarando apoio à criação da unidade de conservação (Brasil/
IBAMA, 1997). Entre os motivos expostos na solicitação, estava:

(A) degradação ambiental provocada pela extração predatória do palmito de açaí, realizada por grandes empresas oriundas de outras regiões, que não entendem a necessidade de conservação dos recursos naturais por populações extrativistas. Daí a necessidade de se conservar os recursos naturais para que as famílias possam retirar o seu sustento das referidas áreas sem destruí-las. Considerando que a Gleba 'Terra Grande' é um grande ecossistema de grande importância e dela tiramos nosso sustento (Brasil/IBAMA, 1997, p. 2).

Após nove anos de espera e muita luta, através do Decreto Federal $\mathrm{n}^{\mathrm{o}}$ (s/n), de 05 de junho de 2006 (Brasil, 2006), foi criada a Reserva Extrativista Terra Grande - Pracuúba. "Foi depois da reserva que veio melhorar, porque parou a perseguição, né?" (Dona Conceição, 76 anos, 11/06/2016, Serafina). Na luta por sua própria sobrevivência e reprodução social, os povos tradicionais lutam historicamente pela conservação de seus territórios. Se estes são hoje passíveis de serem conservados - ao invés de recuperados - mérito daqueles que ocupam historicamente tais territórios. Sorte da "Terra Grande" em ter esses povos enquanto ocupantes e transformadores de sua base material.

Teve uma vez, já estava esfriando o negócio e aí voltaram há tirar palmito. Fizeram um alojamento no Pimental. Tinham treze tapitis lá. Treze pessoas com família tirando palmito lá. Eram de Curralinho. Eram contratados da empresa pra tirar o palmito[...] Aí nós fomos lá. Estava lá o encarregado deles[...] Aí nós chegamos lá: 'Olha, nós viemos derrubar todos esses tapiris ${ }^{15}$ '. Aí (os palmiteiros) : 'Aqui tu não vai derrubar!'(Liderança da Terra Grande): ‘Não vai?’Aí

\footnotetext{
${ }^{15}$ Abrigos feitos de madeira (ou troncos de palmeiras) coberta com palhas ou outro tipo de fibra vegetal.
} 
eu tinha um cunhado aí que ele era maluco também[...] Ele puxou o rádio VHS - porque eles tinham o rádio funil aí, sabe? Eles se comunicavam por rádio funil Ele puxou o rádio VHS, jogou a bateria lá pra água, jogou rádio pra lá[...] E nós metemos o machado. E eles tiravam as redes. Quem tirava a rede tirava; quem tirava as sacolas tirava; nós derrubamos tudinho. Não derrubamos com exceção um tapiri, que o cara disse assim: 'Não, meu amigo, não derrube. Eu estou doente, minha mulher também tá'. E ele estava mordido de aranha, estava doente lá na rede. (Liderança da Terra Grande): 'Não, o seu tapiri vai ficar em pé, mas amanhã, a hora que tu sair daqui, tu derruba ele. Não queremos um tapiri desse em pé'. Ele disse: 'Não, eu derrubo' (Josias, 09/06/2016, Serafina).

Em uma situação hipotética, se os grupos domésticos da Serafina (e outros das comunidades Pimental e Passagem Grande que se envolveram no mesmo movimento de resistência) não ocupassem a Terra Grande ou não tivessem resistido às investidas das madeireiras e empresas de exploração e beneficiamento de palmito sobre seus territórios, os ecossistemas existentes neste território tradicional estariam com seus atributos ecológicos conservados tal como estão hoje? Nesse sentido, é possível afirmar que as práticas tradicionais dessas comunidades são as principais responsáveis pela preservação ambiental local?

No Brasil, segundo Almeida (2010, p. 139), "embora sejam elevados os índices de concentração fundiária, não é nos grandes imóveis rurais que se encontram as áreas preservadas mais significativas. Estas estão localizadas nas terras tradicionalmente ocupadas", dentre as quais temos as pertencentes às unidades familiares agroextrativistas que habitam as margens dos estuários e rios amazônicos.
No entanto, este relato não deve ser compreendido sem a devida visão crítica, no intuito de evitar atribuir aos povos e comunidades tradicionais

...o mero papel de guardiões de ecossistemas. Isso não corresponderia nem aos conflitos que enfrentam, raramente decorrente desse papel, nem à maneira como eles próprios se vêem[...] essa identidade se refere às suas atividades econômicas. Território apresenta múltiplos sentidos, dentre os quais está o espaço de produção e de reprodução (Leroy \& Meireles, 2013, p. 119).

Alguns pesquisadores dentro do campo ambientalista defendem que os modos de produção e reprodução dos povos e comunidades tradicionais seriam 'imutáveis' e, em função disso, manteriam capacidade limitada de produzirem transformações no ambiente, conservando seus territórios tradicionais. Determinados autores, por outro lado, vêm insistindo na compreensão da tradição e dos povos e comunidades tradicionais enquanto sujeitos sócio-históricos, transformados pelo mundo e através das diferentes gerações, ao mesmo tempo que são transformadores daquele através dessas (Costa \& Macedo, 2016).

A partir das observações da presente pesquisa, esse último entendimento é o que nos parece mais pertinente, e não só do ponto de quem luta por mais justiça social, mas também sob o olhar de quem também busca respostas à atual crise ambiental. Conforme discussões realizadas, um fator que parece ter contribuído para o sucesso da instalação da fábrica de extração e beneficiamento de palmito no Alto Canaticú - possibilitando assim a exploração predatória dos recursos naturais presentes na Terra Grande - foram as desigualdades oriundas da alta 
concentração de capital existentes entre a empresa e a comunidade Timbotuba.

A partir da detenção de meios de produção que os agroextrativistas do Timbotuba não tinham acesso, a empresa articulou 'acordos simbióticos' com esses moradores locais. Entre esses fundamentais acordos, estão tanto os que propiciaram a disponibilização do espaço para a instalação da fábrica no Alto Canaticú quanto os que garantiram a oferta da força de trabalho necessária para o funcionamento e reprodução do empreendimento capitalista.

Assim sendo, nos parece que alegações a favor de uma eventual imutabilidade das técnicas e conhecimentos dos povos e comunidades tradicionais não contribuem inclusive com a conservação de seus territórios, posto que defender tal imutabilidade é defender a manutenção de eventuais relações de poder que favorecem agentes econômicos capitalistas na disputa pelo direito de exploração dos recursos presentes nos territórios ora tradicionalmente ocupados. "Sendo assim, não se trata de deixar de lado o conceito de povos e comunidades tradicionais, mas compreendê-lo em suas limitações e forçar suas bordas, buscando problematizar, contextualizar e ampliar as discussões em torno do tema" (Costa \& Macedo, 2016, p. 226).

Nesse sentido, Costa \& Macedo (2016) apontam alguns estudos sobre o conceito de conhecimento tradicional que, ao invés de suprimir a noção de imutabilidade, parecem deslocá-lo da dimensão temporal para a espacial, defendendo uma tradicionalidade baseada no "reconhecimento do valor irrefutável de um modo de vida local como tal - mantido, assegurado e atestado nas práticas e processos vividos pelos que o compartilham, inclusive no diálogo com a sociedade abrangente"
(Prado, 2012, p, 175 apud Costa \& Macedo, 2016, p. 226-227).

Reconhecemos o valor do modo de vida local representado pelas comunidades tradicionais investigadas. E reconhecemos que este modo de vida tradicional se distingue socioeconomicamente do atual modelo hegemônico de desenvolvimento - capitalista e neoliberal - especialmente pelas três seguintes características:

1. as produções das comunidades investigadas, mesmo quando direcionadas ao mercado, se baseiam em produtos que possuem 'valor de uso', ou seja, que integram o conjunto de bens materiais usufruídos diretamente pelos 'grupos domésticos' produtores. Assim sendo, ao invés da supremacia do 'valor de troca' presente nas sociedades capitalistas, as produções tradicionais em questão estão atreladas fortemente ao 'valor de uso' que possuem para seus produtores;

2. os grupos analisados detêm meios próprios de produção. Nesse sentido, o trabalho assalariado, ainda que presente, não se dá a partir de fronteiras rígidas entre proprietários dos meios de produção e trabalhadores;

3. é um modo de vida estruturado espacialmente de maneira diversa do modelo de desenvolvimento atualmente hegemônico. A alta concentração e mobilidade do capital tende a descolar as atividades econômicas dos donos do capital das demais ocupações voltadas à reprodução social dos mesmos. Já no caso dos povos tradicionais analisados esse descolamento não ocorre.

As diferenças se dão não só no campo do 'visível', no campo das relações socioeconômicas acima, mas também no campo do 'sensível', nos territórios 
simbólicos daqueles que operam aquelas distintas transformações materiais. Foi possível evidenciar alguns rastros desses processos psíquicos distintos, dessas subjetividades não hegemônicas.

Eu não saía de casa eu acho que quase toda a vida dos meus filhos. Só mesmo para fazer roça. Eu ficava sempre mais em casa, né? (Dona Conceição, 76 anos, 11/06/2016, Serafina).

Que vida restrita e sem liberdades foi a maternidade para esta mulher. Este foi o sentimento do pesquisador quando em campo ouviu tal relato, haja vista que essa matriarca só saia de casa para fazer as roças. Estas, por proibições impostas pelo dono do seringal aos seringueiros, foram por muito tempo feitas fora da Fazenda Terra Grande: "Nós trabalhamos muito fora, lá pra banda do Timbotuba[...] doze anos nós trabalhamos[...]Já estava cansada de ir pra lá fazer farinha, de capinar roça (Dona Conceição, 76 anos, 11/06/2016, Serafina).

No entanto, tal impressão foi abalada a partir da escuta atenta do áudio da entrevista de uma das filhas da matriarca. Ao relembrar da época da sua infância, ela diz: "a mamãe acompanhava a gente. Mamãe cortava muita seringueira, era[...] Os dois velhos é que cortavam mais" (Dona Josefina, 09/06/2016, Serafina).

À primeira vista, parece contraditório que a matriarca da Serafina diga que só saía de casa para fazer a roça na comunidade Timbotuba, sendo que passava boa parte de seu dia riscando seringueira nas estradas inseridas em sua comunidade. Entretanto, é possível ressignificarmos esse estranhamento inicial - ao menos para um pesquisador vindo de um local onde os limites da 'casa' se encerram entre paredes ou muros - ao buscarmos compreender o lugar e a perspectiva da matriarca que nasceu e foi criada na 'Terra Grande'. Se assumirmos que a noção de "casa" dessa agroextrativista engloba não só os limites da estrutura de madeira na qual pernoita, mas também engloba o quintal, o sítio e as áreas de produção localizadas em suas imediações, entre as quais as estradas de seringueiras onde trabalhava, o relato desta antiga moradora e agroextrativista perde em contradição para ganhar clareza e sentido. Quando se refere a sua casa, a matriarca parece falar sobre o espaço que nós (urbanos ocidentais) designamos comumente como o território tradicional.

A própria arquitetura de algumas das estruturas de madeira suspensas sobre 'palafitas" ${ }^{16}$ que abrigam o núcleo doméstico agroextrativista - que é até onde comumente na cultura urbano ocidental limita-se o conceito "casa" - não raro expressam essa perspectiva. Os agroextrativistas-construtores das comunidades investigadas muitas vezes não erguem totalmente algumas paredes dessa "casa"; não erguem fronteiras entre esta e o território onde se inserem enquanto produtores locais, como se um fosse extensão do outro.

\section{Considerações finais}

Partindo da compreensão de que as relações ambientais são mediadas pelo trabalho, foi possível perceber que os distintos modos de produção e de reprodução social dos povos e comunidades tradicionais pesquisados são fontes de subsídios e potenciais alternativas frente à atual crise ambiental. Tal

\footnotetext{
${ }^{16}$ Troncos de madeira trabalhados e sobre os quais são erguidas estruturas na beira do rio.
} 
vocação pode ser potencializada ou enfraquecida, a depender das estratégias assumidas pelos grupos sociais envolvidos e das políticas públicas implementadas pelo Estado. Caso os direitos desses povos sejam reconhecidos, com sua valorização enquanto detentores de configurações socioeconômicas e subjetivas que propiciam relações territoriais distintas da atualmente hegemônica, a luta por mais justiça social, diversidade cultural e viabilidade ambiental tende a ganhar aliados e força.

Uma estratégia que tende a potencializar as contribuições dos povos e comunidades tradicionais nessa luta é o fomento em meios de produção adequados às necessidades e suficientes aos anseios desses povos. Tal fomento, especialmente quando direcionado às produções com 'valores de uso', favorece a autonomia socioeconômica e política e, consequentemente, as chances desses povos manterem controle sobre seus territórios tradicionalmente conservados. Esse ganho de autonomia, fundamentado no controle territorial (viável através das RESEXs) e potencializado no fomento produtivo, tende a refletir-se numa maior resiliência das práticas e ocupações tradicionais frente a ameaças externas. Dentre tais ameaças se encontram projetos capitalistas que buscam, nas tensões oriundas da alta concentração do capital, viabilizar a instituição de relações de exploração predatória tanto de corpos quanto de territórios e seus recursos naturais.

Mesmo sob uma ótica estritamente voltada aos interesses da conservação ambiental, é importante que a tradição seja compreendida enquanto imutabilidade locacional ao invés de temporal. Reconhecer os modos tradicionais de produção enquanto continuidade somente daquilo que é essencial para a segurança, autonomia e qualidade de vida desses povos. Ao estimular possibilidades e oportunidades de transformação, inclusive dos meios, das tecnologias e métodos de produção; potencializa-se não só a autonomia e emancipação socioeconômica dessas comunidades, mas também a resistência de práticas e ocupações tradicionais espacialmente integradas e viáveis ambientalmente às tentativas de expropriação predatórias do modo de produção baseado na concentração e mobilidade do capital.

Formas e concepções alternativas de produção (material e imaterial), a exemplo dos modos tradicionais, podem contribuir não só na resolução das problemáticas econômicas e sociais de nosso tempo, mas também no enfrentamento da atual crise ambiental.

\section{Referências}

Acselrad, H. As práticas espaciais e o campo dos conflitos ambientais. In: Acselrad, H. (Org.). Conflitos ambientais no Brasil. Rio de Janeiro: Relume-Dumará: Fundação Heinrich Böll, p. 13-35, 2004.

Almeida, A. W. B. de. Agroestratégias e desterritorialização: direitos territoriais e étnicos na mira dos estrategistas dos agronegócios. In: Almeida. A. W. B. de; Zhouri, A.; Ioris, A. A. R.; Brandão, C.; Bermann, C.; Hernández, F. M.; Bezerra, G. N.; Acselrad, H.; Paula, J. A. de; Laschefski, K.; Coelho, M. C. N.; Monteiro, M. A.; Garzon, L. F. N.; Cunha, L. H.; e Wanderley, L. J. (Org.). Capitalismo globalizado e recursos territoriais-fronteiras da acumulação no Brasil contemporâneo. Rio de Janeiro: Ed. Lamparina, p. 101-143, 2010.

Alvarenga, L.; Costa, S. L. Produção artesanal: documentação e divulgação audiovisual como tecnologias de valorização sociocultural. Cadernos de Terapia Ocupacional da UFSCar, 24, 155-162, 2016. doi: 10.4322/0104-4931. ctoAO0668

Brasil. Decreto s/n. ${ }^{\circ}$, de 05 de junho de 2006. Dispõe sobre a criação da Reserva Extrativista Terra Grande - Pracuúba, 
nos Municípios de Curralinho e São Sebastião da Boa Vista, no Estado do Pará, e dá outras providências. Brasília: DOU de 06/06/2006.

Brasil. Decreto $n .{ }^{\circ}$ 6040, de 07 de fevereiro de 2007. Institui a Política Nacional de Desenvolvimento Sustentável dos Povos e Comunidades Tradicionais. Brasília: DOU de 08/02/2007.

Brasil. Lei ${ }^{\circ} 9.985$, de 18 de julho de 2000. Regulamenta o art. 225, § 1o, incisos I, II, III e VII da Constituição Federal, institui o Sistema Nacional de Unidades de Conservação da Natureza e dá outras providências. Brasília: DOU de 19/07/2000.

Brasil/IBAMA. Processo de Criação da Reserva Extrativista Terra Grande Paracuúba. Processo no 02018.005990/9751, 1997, dois volumes, 328 páginas.

Brasil/ICMBio. Mapa da RESEX com a identificação das comunidades, rios, centros urbanos dos municipios de Curralinho e São Sebastião da Boa Vista e a fábrica de extração e beneficiamento de palmito, 2011. Acervo da RESEX Terra Grande-Pracuúba.

Costa, S. L. Terapia ocupacional social: dilemas e possibilidades da atuação junto a povos e comunidades tradicionais. Cadernos de Terapia Ocupacional da UFSCar, 20, 43-54, 2012. doi: 10.4322/cto.2012.005

Costa, S. L.; Macedo, M D. Povos e Comunidades Tradicionais. In: Lopes, R. E.; Malfitano, A. P. S. (Orgs.). Terapia ocupacional social: desenhos teóricos e contornos práticos. São Carlos: Editora UFSCar, p. 221-240, 2016.

Cruz, W. P. da S. Educação e conservação da biodiversidade no contexto escolar da Reserva Extrativista Terra Grande-Pracuúba. Belém, Dissertação (Mestrado em Educação) - UFPA, 2014.

Duarte, L. F. D. As redes do suor: A reprodução social dos trabalhadores da pesca em Jurujuba. Niterói: EdUFF,1999.
Espaço Educar. Mapa político do Brasil, 2008. Disponível em: <http://www.espacoeducar.net/2008/02/atlas_08. html).>. Acesso em: jun. 2018.

Foladori, G. Limites do desenvolvimento sustentável. Campinas: Unicamp, 2001.

Leher, R. Prefácio: Uma penetrante perspectiva teórica para compreender como os dominantes dominam. In: Neves, L. M. W. (Org.). Direita para o social e esquerda para o capital: intelectuais da nova pedagogia da hegemonia no Brasil. Niterói: Editora Xamã, p. 14 -18, 2010.

Leroy, J. P.; Meireles, J. Povos indígenas e comunidades tradicionais: os visados territórios dos invisíveis. In: Porto, M. F.; Pacheco, T.; Leroy, J. P. (Orgs.). Injustiça ambiental e saúde no Brasil: o mapa de conflitos. Rio de Janeiro: Editora Fiocruz, p. 115-131, 2013.

Loureiro, C. F. B.; Layrargues, P. P. Ecologia política, justiça e educação ambiental crítica: perspectivas de aliança contra-hegemônica. Trabalho, educação e saúde, 11, 53-71, 2013. doi: 10.1590/S1981-77462013000100004

Mourão, L. História e natureza: do açaí ao palmito. Territórios e Fronteiras, 3(2), 74-96, 2010.

Pacheco, T.; Faustino, C. A iniludível e desumana prevalência do racismo ambiental nos conflitos do mapa. In: Porto, M. F.; Pacheco, T.; Leroy, J. P. (Orgs.). Injustiça ambiental e saúde no Brasil: o mapa de conflitos. Rio de Janeiro: Editora Fiocruz, p.73-114, 2013.

Silva, A. A.; Silva, A. C. G.; Paula, J. M.; Silva, J. C.; Sousa, L. F. O processo de des (re) territorialização dos trabalhadores nordestinos no território amazônico durante os ciclos da borracha. Revista Geografar, 5, 61-82, 2010. doi: 10.5380/geografar.v5i1.17782

Veronese, M. V.; Guareschi, P. Possibilidades solidárias e emancipatórias do trabalho: campo fértil para a prática da psicologia social crítica. Psicologia \& Sociedade, 17, 58-6, 2005. 